\section{Response to the letter to the editor by Hafer and Johnson concerning 'Mechanism of action of HTX-011: a novel, extended-release, dual-acting local anesthetic formulation for postoperative pain'}

\section{To the Editor}

We appreciate the comments provided by Hafer and Johnson ${ }^{1}$ regarding our recent manuscript. ${ }^{2}$ Their primary concern appears to be the clinical evidence supporting the analgesic properties of HTX-011 beyond 24 hours.

HTX-011 is a dual-acting local anesthetic consisting of bupivacaine and lowdose meloxicam in an extended-release polymer. Preclinical data demonstrated that meloxicam normalized the local $\mathrm{pH}$ at the surgical site and synergistically potentiated the magnitude and duration of analgesic activity of bupivacaine in a pig postoperative pain model through 72 hours. The early proof-of-concept phase II bunionectomy study presented in our manuscript ${ }^{2}$ confirmed the preclinical findings and demonstrated that HTX-011 resulted in greater pain reduction than either extended-release bupivacaine or extended-release meloxicam through 72 hours following surgery. Moreover, HTX-011 significantly reduced mean pain intensity 24 to 72 hours post surgery when compared with extended-release bupivacaine (area under the concentration time curve (AUC) ${ }_{24-72}, 252.2$ vs 312.3, $\mathrm{p}=0.0156)$, validating that meloxicam does indeed potentiate the effect of bupivacaine in HTX-011 beyond the first 24 hours.
Drs. Hafer and Johnson suggest that further investigation is needed to validate the clinical efficacy of HTX-011 beyond 24 hours. ${ }^{1}$ Two published phase III studies (EPOCH-1 (bunionectomy) and EPOCH-2 (herniorrhaphy)) ${ }^{3}{ }^{4}$ provide such evidence. In EPOCH-1, HTX-011 demonstrated a significant reduction in mean pain intensity over 72 hours $\left(\mathrm{AUC}_{0-72}\right)$ compared with saline placebo $(\mathrm{p}<0.0001)$ and bupivacaine $\mathrm{HCl}$ $(p=0.0002){ }^{3}$ Importantly, the analgesic benefit continued beyond 24 hours as HTX-011 demonstrated significantly lower mean pain scores from 24 to 72 hours $\left(\mathrm{AUC}_{24-72}\right)$ compared with saline placebo $(\mathrm{p}<0.0001)$ and bupivacaine $\mathrm{HCl}$ $(p=0.0072)^{3} \quad$ (table 1), confirming that the efficacy observed through 72 hours was not merely a carry-over from the efficacy observed in the first 24 hours. Similar results were observed in EPOCH-2, with HTX-011 providing superior pain reduction compared with saline placebo and bupivacaine $\mathrm{HCl}$ through 72 hours (both $\mathrm{p}<0.001$ ) and specifically from 24 to 72 hours $(p=0.0264$ and $p=0.0007$, respectively), again confirming that HTX-011 continues to provide sustained

Table 1 Select efficacy results from HTX-011 phase III studies, EPOCH-1 (bunionectomy) and EPOCH-2 (herniorrhaphy) ) $^{3-5}$

EPOCH-1 EPOCH-2

\begin{tabular}{|c|c|c|c|c|c|c|}
\hline & $\begin{array}{l}\text { Saline placebo } \\
(n=100)\end{array}$ & $\begin{array}{l}\text { Bupivacaine } \mathrm{HCl} \\
50 \mathrm{mg} \\
(\mathrm{n}=155)\end{array}$ & $\begin{array}{l}\text { HTX-011 } \\
60 \mathrm{mg} / 1.8 \mathrm{mg} \\
(\mathrm{n}=157)\end{array}$ & $\begin{array}{l}\text { Saline placebo } \\
(n=82)\end{array}$ & $\begin{array}{l}\text { Bupivacaine } \mathrm{HCl} \\
75 \mathrm{mg} \\
(\mathrm{n}=172)\end{array}$ & $\begin{array}{l}\text { HTX-011 } \\
300 \mathrm{mg} / 9 \mathrm{mg} \\
(\mathrm{n}=164)\end{array}$ \\
\hline \multicolumn{7}{|l|}{ Pain intensity } \\
\hline \multicolumn{7}{|l|}{$\mathrm{AUC}_{0.24}$ of the NRS pain intensity scores } \\
\hline Mean (SD) & $155.8(48.49)$ & $131.4(48.86)$ & $98.7(59.55)$ & $143.8(54.94)$ & $126.7(52.68)$ & $97.7(60.31)$ \\
\hline$P$ value vs saline placebo & & 0.0004 & $<0.0001$ & & 0.0238 & $<0.0001$ \\
\hline$P$ value vs bupivacaine $\mathrm{HCl}$ & & & $<0.0001$ & & & $<0.0001$ \\
\hline \multicolumn{7}{|l|}{$\mathrm{AUC}_{24.72}$ of the NRS pain intensity scores } \\
\hline Mean (SD) & $289.6(115.64)$ & $262.1(117.25)$ & $224.6(131.28)$ & $207.1(122.32)$ & $215.2(111.97)$ & $171.7(120.40)$ \\
\hline$P$ value vs saline placebo & & 0.0806 & $<0.0001$ & & 0.6041 & 0.0264 \\
\hline$P$ value vs bupivacaine $\mathrm{HCl}$ & & & 0.0072 & & & 0.0007 \\
\hline \multicolumn{7}{|l|}{ Opioid use } \\
\hline \multicolumn{7}{|l|}{ Opioid consumption from 0 to 24 hours (MME) } \\
\hline Mean (SD) & $14.1(8.58)$ & $11.8(9.39)$ & $7.4(7.82)$ & $11.7(10.82)$ & $7.3(8.61)$ & $5.2(7.86)$ \\
\hline Median (min, max) & $14.0(0.0$ to 45.0$)$ & $10.0(0.0$ to 44.0$)$ & $5.0(0.0$ to 29.0$)$ & $9.8(0.0$ to 37.0$)$ & $5.0(0.0$ to 37.0$)$ & $0.0(0.0$ to 35.0$)$ \\
\hline$P$ value vs saline placebo & & & $<0.0001$ & & & $<0.0001$ \\
\hline$P$ value vs bupivacaine $\mathrm{HCl}$ & & & $<0.0001$ & & & 0.0073 \\
\hline \multicolumn{7}{|l|}{ Opioid consumption from 24 to 72 hours (MME) } \\
\hline Mean (SD) & $15.9(14.77)$ & $13.3(14.56)$ & $11.4(13.64)$ & $5.9(9.30)$ & $7.2(11.10)$ & $5.62(11.09)$ \\
\hline Median (min, max) & $12.5(0.0$ to 60.0$)$ & $8.0(0.0$ to 57.0$)$ & $5.0(0.0$ to 54.0$)$ & $0.0(0.0$ to 37.0$)$ & $0.0(0.0$ to 69.0$)$ & $0.0(0.0$ to 68.0$)$ \\
\hline$P$ value vs saline placebo & & & 0.0024 & & & 0.2532 \\
\hline$P$ value vs bupivacaine $\mathrm{HCl}$ & & & 0.1585 & & & 0.0161 \\
\hline \multicolumn{7}{|l|}{ Opioid-free } \\
\hline$\%$ patients opioid-free through 72 hours & $2 \%$ & $11 \%$ & $29 \%$ & $22 \%$ & $40 \%$ & $51 \%$ \\
\hline$P$ value vs saline placebo & & & $<0.0001$ & & & $<0.0001$ \\
\hline$P$ value vs bupivacaine $\mathrm{HCl}$ & & & 0.0001 & & & 0.0486 \\
\hline
\end{tabular}

AUC, area under the concentration time curve; MME, morphine milligram equivalents; NRS, numeric rating scale. 
and superior analgesia beyond the first 24 hours. $^{4}$

The beneficial effects of HTX-011 on opioid reduction were also confirmed to persist beyond 24 hours in the phase III studies. In both studies, HTX-011 significantly reduced opioid consumption and enabled significantly more patients to recover without requiring any opioids (opioid-free) throughout the 72 hours postoperative period compared with both saline placebo and bupivacaine $\mathrm{HCl}$ ( $\mathrm{p}$ values ranging from $\mathrm{p}<0.001$ to $\mathrm{p}<0.05) .^{3} 4$ In EPOCH-1, HTX-011 treatment reduced opioid consumption by $48 \%$ versus saline placebo and by $37 \%$ versus bupivacaine $\mathrm{HCl}$ over the first 24 hours following surgery (both $\mathrm{p}<0.0001$; table 1). ${ }^{5}$ Efficacy extended beyond 24 hours as HTX-011 significantly reduced opioid use between 24 and 72 hours versus saline placebo $(p=0.0024)$, and decreased opioid use versus bupivacaine $\mathrm{HCl}^{5}$ In $\mathrm{EPOCH}-2$, HTX-011 significantly reduced opioid use during the first 24 hours $(\mathrm{p}<0.0001$ vs saline placebo, $p=0.0073$ vs bupivacaine $\mathrm{HCl}$ ), with continued reduction between 24 and 72 hours versus bupivacaine $\mathrm{HCl}$ $(\mathrm{p}=0.0161) .^{5}$

These phase III studies confirm that HTX-011 provides sustained and superior analgesic efficacy throughout the 72 hour postoperative period with significantly lower pain scores, reduced opioid consumption, and more opioid-free patients compared to placebo and bupivacaine $\mathrm{HCl}$. Together, the preclinical and clinical data support the mechanism of action (MOA) put forth in our publication. ${ }^{2}$ In addition, our proposed MOA is consistent with the established phenomenon of acidic $\mathrm{pH}$ limiting the duration of action of local anesthetics. ${ }^{67}$ We hope the consistent clinical efficacy observed across several studies, including in the 24 to 72 hours window, reassures Drs. Hafer and Johnson, along with their colleagues, of the 72 hours duration of action of HTX-011.

Thomas Ottoboni, ${ }^{1}$ Barry Quart, ${ }^{1}$ Jayne Pawasauskas, ${ }^{2}$ Joseph F Dasta, ${ }^{3,4}$ Richard A Pollak, ${ }^{5}$ Eugene R Viscusi ${ }^{6}{ }^{6}$

${ }^{1}$ Heron Therapeutics, Inc, San Diego, California, USA ${ }^{2}$ College of Pharmacy, University of Rhode Island, Kingston, Rhode Island, USA

${ }^{3}$ College of Pharmacy, Ohio State University, Columbus, Ohio, USA

${ }^{4}$ College of Pharmacy, University of Texas, Austin, Texas, USA

${ }^{5}$ Endeavor Clinical Trials, San Antonio, Texas, USA

${ }^{6}$ Sidney Kimmel Medical College of Thomas Jefferson

University, Philadelphia, Pennsylvania, USA

Correspondence to Dr Thomas Ottoboni, Heron Therapeutics, 4242 Campus Point Ct \#200, San Diego CA 92121, USA; TOttoboni@herontx.com

Contributors $\mathrm{TO}$ and $\mathrm{BQ}$ drafted the initial version of this letter; all remaining authors (JP, JFD, RAP, ERV) reviewed, revised content, and approved the final version.

Funding This study was funded by Heron Therapeutics (NA).

Competing interests $\mathrm{TO}$ and $\mathrm{BQ}$ are employees of Heron Therapeutics and receive salary and stock options. JP received consulting fees from Heron Therapeutics, Acacia Pharma, and Mallinckrodt Pharmaceuticals and is on the speaker's bureau for Mallinckrodt Pharmaceuticals. JFD receives consulting fees from Heron Therapeutics, AcelRx Pharmaceuticals, Neumentum Pharmaceuticals, Aries Pharmaceuticals, and Pacira Pharmaceuticals. ERV receives consulting fees from AcelRx, Concentric, Heron Therapeutics, Innacoll, Merck, Neumentum, Pfizer, Recro, Salix, and Trevena.

Patient consent for publication Not required.

Provenance and peer review Not commissioned; internally peer reviewed.

\section{(อ) \\ OPEN ACCESS}

Open access This is an open access article distributed in accordance with the Creative Commons Attribution Non Commercial (CC BY-NC 4.0) license, which permits others to distribute, remix, adapt, build upon this work non-commercially, and license their derivative works on different terms, provided the original work is properly cited, an indication of whether changes were made, and the use is non-commercial. See: http:// creativecommons.org/licenses/by-nc/4.0/.

(C) American Society of Regional Anesthesia \& Pain Medicine 2020. Re-use permitted under CC BY-NC. No commercial re-use. Published by BMJ.

A Check for updates

To cite Ottoboni T, Quart B, Pawasauskas J, et al. Reg Anesth Pain Med 2020;45:1031-1032.

Received 23 March 2020

Accepted 26 March 2020

Published Online First 2 June 2020

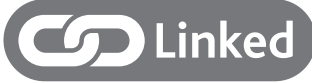

- http://dx.doi.org/10.1136/rapm-2020-101430

Reg Anesth Pain Med 2020;45:1031-1032. doi:10.1136/rapm-2020-101488

ORCID iD

Eugene R Viscusi http://orcid.org/0000-0003-02604396

\section{REFERENCES}

1 Hafer J, Johnson KB. Mechanism of action of HTX-011: a novel, extended-release, dual-acting local anesthetic formulation for postoperative pain. Reg Anesth Pain Med 2020;45:1030-1.

2 Ottoboni T, Quart B, Pawasauskas J, et al. Mechanism of action of HTX-011: a novel, extended-release, dualacting local anesthetic formulation for postoperative pain. Reg Anesth Pain Med 2020;45:117-23.

3 Viscusi E, Gimbel JS, Pollack RA, et al. HTX-011 reduced pain intensity and opioid consumption versus bupivacaine $\mathrm{HCl}$ in bunionectomy: phase III results from the randomized epoch 1 study. Reg Anesth Pain Med 2019;44:700-6.

4 Viscusi E, Minkowitz H, Winkle P, et al. HTX-011 reduced pain intensity and opioid consumption versus bupivacaine $\mathrm{HCl}$ in herniorrhaphy: results from the phase 3 epoch 2 study. Hernia 2019;23:1071-80.

5 Heron Therapeutics, Inc. Data on file, 2019.

6 Hargreaves KM, Keiser K. Local anesthetic failure in endodontics: mechanisms and management. Endod Topics 2002:1:26-39.

7 Ueno T, Tsuchiya H, Mizogami M, et al. Local anesthetic failure associated with inflammation: verification of the acidosis mechanism and the hypothetic participation of inflammatory peroxynitrite. J Inflamm Res 2008;1:41-8. 